BRES 24184

\title{
Two types of quisqualate receptors are decreased in human olivopontocerebellar atrophy cerebellar cortex
}

\author{
Richard L. Makowiec ${ }^{1}$, Roger L. Albin ${ }^{1}$, Jang-Ho J. Cha ${ }^{2}$, Anne B. Young ${ }^{1}$ and Sid Gilman ${ }^{1}$ \\ ${ }^{1}$ Department of Neurology and the ${ }^{2}$ Neuroscience Program, University of Michigan, Ann Arbor, MI 48104-1687 (U.S.A.)
}

(Accepted 3 April 1990)

Key words: Olivopontocerebellar atrophy; Cerebellar cortex; Quisqualate; $\alpha$-Amino-3-hydroxy-5-methylisoxazole-4-propionate; Purkinje cell

\begin{abstract}
We used receptor autoradiography to study the distribution of ionotropic and metabotropic quisqualate (QA) receptors in normal human cerebellar cortex and cerebellar cortex from 7 cases of olivopontocerebellar atrophy (OPCA). In normal human cerebellar cortex, both types of QA receptors were densest in the molecular layer. Both ionotropic and metabotropic QA receptors were significantly diminished in the molecular layer of OPCA specimens. These results suggest that both ionotropic and metabotropic QA receptors are localized on Purkinje cell dendrites.
\end{abstract}

The cerebellar cortex is a convenient region in which to study excitatory amino acid (EAA) receptors because cerebellar neuronal circuitry is relatively well understood $^{12,18}$. Morphological and neurochemical evidence supports a neurotransmitter function for EAAs in the cerebellar cortex with glutamate as the possible neurotransmitter of mossy and parallel fibers and aspartate as the possible neurotransmitter of climbing fibers ${ }^{8,11,28,30}$. Electrophysiological evidence indicates that the excitatory actions of EAAs are mediated by at least 3 subtypes of ion channel-linked ('ionotropic') receptors named for the agonists which preferentially excite them: $N$-methyl$\mathrm{D}$-aspartate, kainate, and quisqualate ${ }^{5}$. In addition, a quisqualate preferring 'metabotropic' receptor linked to inositol phospholipid metabolism has been reported recently ${ }^{25,26}$. Receptor binding studies in animals with genetic, toxic, or viral induced depletions of cerebellar cell types and afferents have been used to determine the cellular localization of EAA receptor subtypes in the cerebellar cortex ${ }^{2,4,17,21}$. In particular, accumulated evidence suggests that both ionotropic and metabotropic quisqualate receptors are located on Purkinje cell dendrites $^{3,4,13-15,17}$.

We have previously reported the distribution and cellular localization of quisqualate-displaceable $\left[{ }^{3} \mathrm{H}\right]$ glutamate binding in human cerebellar cortex using an assay which likely identifies but does not discriminate both the ionotropic and metabotropic quisqualate receptors ${ }^{1}$. In order to provide further information regarding the regional and cellular localization of quisqualate receptors in human brain, we undertook an autoradiographic study of ionotropic and metabotropic quisqualate receptors in the cerebellar cortex of neurologically normal individuals and patients with olivopontocerebellar atrophy (OPCA), a degenerative disorder characterized by degeneration of cerebellar cortical neurons, particularly Purkinje cells9.

Blocks of cerebellar cortex were obtained at autopsy from 15 individuals and stored at $-70^{\circ} \mathrm{C}$. For controls, we used 4 specimens from individuals without neurologic disease, and 4 from individuals with neurologic disease not affecting the cerebellar cortex. There was one case of multiple sclerosis, one case of Friedreich's ataxia, one case of Huntington's disease, and one case of Alzheimer's disease. The mean age at death of controls was 54 years and the mean post-mortem delay was $13.7 \mathrm{~h}$. Specimens from individuals with neurologic disease not affecting the cerebellar cortex were included to control for the effects of chronic neurologic disease and motor disability. As there were no significant differences in receptor density between neurologically normal and abnormal control specimens, results from these two groups were pooled for comparison with results from the OPCA specimens. We studied 7 cases of pathologically verified OPCA. Two cases were sporadic, the remaining 5 from pedigrees with autosomal dominant inheritance. Two of the latter cases were from a well studied pedigree $^{24}$. The mean age at death was 44.4 years and the mean post-mortem delay was $4.0 \mathrm{~h}$.

Correspondence: R.L. Albin, University of Michigan, Neuroscience Laboratory Building, 1103 East Huron, Ann Arbor, MI 48104-1687, U.S.A. 


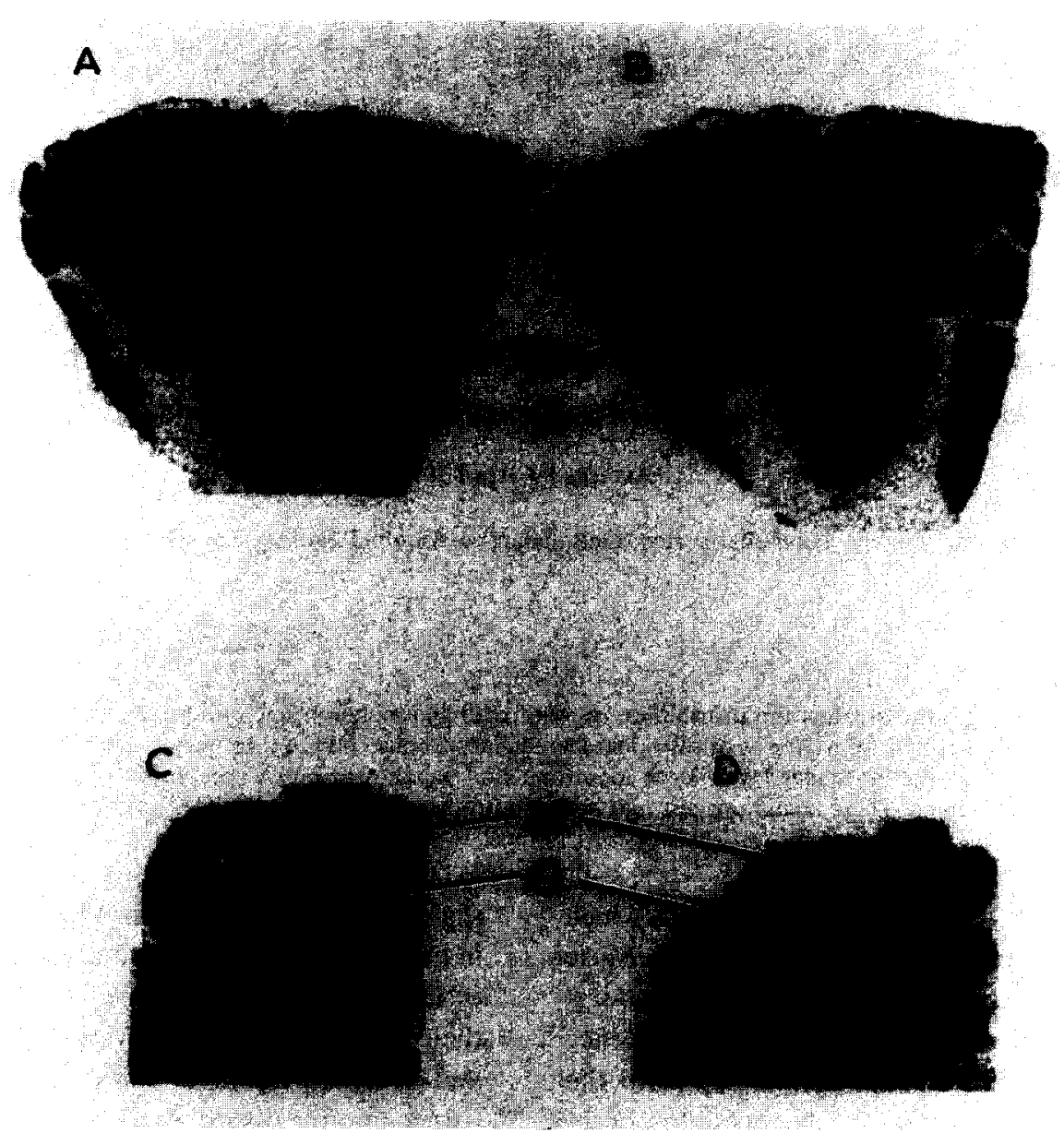

Fig. 1. Autoradiographs of $\left[{ }^{3} \mathrm{H}\right]$ glutamate binding in the presence of $10 \mu \mathrm{M}$ AMPA and $100 \mu \mathrm{M}$ NMDA (a measure of metabotropic quisqualate receptors) in normal human cerebellar cortex (A), OPCA cerebellar cortex (C) and [ $\left.{ }^{3} \mathrm{H}\right]$ AMPA binding (a measure of ionotropic quisqualate receptors) in normal human cerebellar cortex (B) and OPCA cerebellar cortex (D). Both ionotropic and metabotropic receptor densities are markedly reduced in the molecular layer of OPCA specimens and not significantly reduced in the granule cell layer. These autoradiographs represent total binding taken from two separate experiments and thus do not reflect relative receptor densities. Also, numerical data, as reported, represent total binding minus non-specific binding as stated in the text. $M$, molecular layer, $G$, granule cell layer.

Ionotropic quisqualate receptors were labelled with $\left[{ }^{3} \mathrm{H}\right](\mathrm{RS})$ - $\alpha$-amino-3-hydroxy-5-methylisoxazole-4-propionate ([ ${ }^{3}$ H]AMPA). We have recently described an autoradiographic method to label metabotropic quisqualate receptors by using $\left[{ }^{3} \mathrm{H}\right] \mathrm{glutamate}$ and selective incubation conditions ${ }^{4}$. The binding of $\left[{ }^{3} \mathrm{H}\right] \mathrm{AMPA}$ to ionotropic quisqualate receptors was performed according to previously published methods, and the binding of $\left[{ }^{3} \mathrm{H}\right]$ glutamate to metabotropic receptors was performed by the method of Cha et al ${ }^{4,19,20}$. Briefly, $20 \mu \mathrm{m}$ sections were cut from tissue blocks and thaw-mounted onto gelatin-coated slides. Slides for both assays were prewashed for $30 \mathrm{~min}$ at $4{ }^{\circ} \mathrm{C}$ in buffer $(50 \mathrm{mM}$ Tris- $\mathrm{HCl}+$ $\left.2.5 \mathrm{mM} \mathrm{CaCl}_{2}+100 \mathrm{mM} \mathrm{KSCN}, \mathrm{pH} 7.2\right)$ and then dried under a stream of cool air. Slides were immersed for 45 min in incubation buffer plus $37 \mathrm{nM}\left[{ }^{3} \mathrm{H}\right]$ AMPA (spec. act. $29.2 \mathrm{Ci} / \mathrm{mmol}$; New England Nuclear) to label ionotropic receptors, or $200 \mathrm{nM}\left[{ }^{3} \mathrm{H}\right]$ glutamate (spec. act.
$46 \mathrm{Ci} / \mathrm{mmol}$; Amersham) in the presence of $100 \mu \mathrm{M}$ $N$-methyl-D-aspartate and $10 \mu \mathrm{M}$ AMPA to label metabotropic receptors. For $\left[{ }^{3} \mathrm{H}\right]$ AMPA binding, non-specific

\section{TABLE I}

Comparison of ionotropic and metabotropic quisqualate receptor density in the molecular layer and granule cell layer in control human and olivopontocerebellar atrophy (OPCA) cerebellar cortex

All values in $\mathrm{pmol} / \mathrm{mg}$ protein (mean \pm S.E.M.)

\begin{tabular}{lccc}
\hline & Control & OPCA & \% Change \\
\hline lonotropic quisqualate receptors $\left.\left(I^{3} \mathrm{H}\right] \mathrm{AMPA}\right)$ & \\
Molecular layer & $1.02 \pm 0.07$ & $0.51 \pm 0.05$ & $-50.2^{*}$ \\
Granule cell layer & $0.25 \pm 0.02$ & $0.20 \pm 0.02$ & -18.7 \\
\multicolumn{4}{c}{ Metabotropic quisqualate receptors $($ AiQs GB) } \\
Molecular layer & $0.14 \pm 0.02$ & $0.04 \pm 0.01$ & $-67.9^{*}$ \\
Granule cell layer & $0.04 \pm 0.01$ & $0.02 \pm 0.01$ & -44.7 \\
\hline
\end{tabular}

${ }^{*} P<0.01$ by the Mann-Whitney $U$-test. 
binding was determined in the presence of $1 \mathrm{mM}$ unlabelled glutamate and represented less than $5 \%$ of total binding. For $\left[{ }^{3} \mathrm{H}\right]$ glutamate binding to metabotropic receptors, non-specific binding was determined in the presence of $2.5 \mu \mathrm{M}$ quisqualate and represented approximately $45 \%$ of total binding. This AMPA-insensitive, quisqualate-sensitive glutamate binding (AiQsGB) has a pharmacological profile consistent with that of the metabotropic EAA receptor and is distinct from that of the AMPA-sensitive ionotropic receptor ${ }^{4}$. After incubation, sections were rinsed 3 times with cold buffer and once with $2.5 \%(\mathrm{v} / \mathrm{v})$ glutaraldehyde in acetone and rapidly dried under a stream of warm air (total rinse time less than $10 \mathrm{~s}$ ). Sections were placed in X-ray cassettes along with known radioactive standards, apposed to tritiumsensitive film (Hyperfilm, Amersham, Corp.), exposed for 2 weeks at $4{ }^{\circ} \mathrm{C}$ and developed in D-19 (Kodak). Autoradiographic images were analyzed by computerassisted densitometry (Imaging Research, St. Catherines, Ont., Canada). The significance of differences between control and OPCA specimens was assessed with the Mann-Whitney $U$-test. In addition, adjacent sections were fixed over paraformaldehyde vapor and stained with Cresyl violet.

In the molecular layer of OPCA cerebellar cortex, mean specific $\left[{ }^{3} \mathrm{H}\right]$ AMPA binding was significantly reduced to $50 \%$ of the control values $(P<0.01)$ but was not significantly altered in the granule cell layer (Table I, Fig. 1). AiQsGB was reduced in the molecular layer of OPCA cerebellar cortex to $32 \%$ of the control values $(P$ $<0.01)$ and there was a non-significant trend towards reduction in the granule cell layer (Table I, Fig. 1). Cresyl violet-stained sections showed a marked loss of Purkinje cells, marked thinning of the molecular layer, and diminution of the granule cell layer.

Although our single point analysis cannot differentiate between a decrease in receptor number or affinity, Tsiotos et al. ${ }^{27}$ have reported saturation studies of $\left[{ }^{3} \mathrm{H}\right]$ glutamate binding in some of the same OPCA cases used in the present study and found that the decrease in binding represents a change in receptor number and not in the affinity of the glutamate binding sites. However, the $\left[{ }^{3} \mathrm{H}\right]$ glutamate binding assay used by Tsiotos et al. ${ }^{27}$ does not discriminate between ionotropic and metabotropic quisqualate receptors. It has been suggested that ionotropic and metabotropic quisqualate receptors are localized on Purkinje cell dendrites ${ }^{3,4,17}$. The OPCA cases analyzed in this study exhibited a marked reduction of Purkinje cells and in previous studies of Purkinje cell deficient nervous mutant mice we have found a similar reduction in $\left[{ }^{3} \mathrm{H}\right]$ AMPA binding ${ }^{17}$. The large decrease in $\left[{ }^{3} \mathrm{H}\right]$ AMPA binding in the molecular layer of OPCA cerebellar cortex supports the hypothesis that ionotropic quisqualate receptors are located on the dendrites of Purkinje neurons in human cerebellum. Our finding of decreased density of AiQsGB in OPCA cerebellar cortex is also similar to studies of Purkinje cell deficient nervous mutant mice ${ }^{4}$. It has recently been hypothesized in rodents that the excitatory amino acid-linked inositol phospholipid second messenger system is most abundant in the cerebellum ${ }^{10}$. With antibodies directed against the $\mathrm{IP}_{3}$ receptor, the cerebellar cortical inositol phospholipid second messenger system has been localized to Purkinje cell dendrites ${ }^{23}$. Furthermore, the highest densities of both $\left[{ }^{3} \mathrm{H}\right] \mathrm{IP}_{3}$ binding and AiQsGB have been reported to be in the molecular layer of cerebellum where Purkinje cell dendrites are located ${ }^{4,29}$. Our finding of a decrease in binding to metabotropic receptors in OPCA cerebellar cortex complements a recent report by Kish et al. ${ }^{16}$ of diminished $\left[{ }^{3} \mathrm{H}\right]$ inositol 1,4,5-triphosphate $\left(\left[{ }^{3} \mathrm{H}\right]\left[\mathrm{IP}_{3}\right)\right.$ binding in OPCA cortical homogenates. Kish et al. ${ }^{16}$ inferred from their OPCA data that the $\mathrm{IP}_{3}$ receptor system is localized to human Purkinje cells and our OPCA data suggest that the inositol phospholipid-linked quisqualate receptor is also localized to human Purkinje cell dendrites.

The present study represents the first autoradiographic analysis of both ionotropic and metabotropic quisqualate receptors in normal human and OPCA cerebellar cortex. Our findings are concordant with prior experimental animal data ${ }^{4,17,20}$. In particular, binding to metabotropic and ionotropic quisqualate receptors in the nervous mutant mouse, which exhibits a marked loss of Purkinje cells, reveals binding characteristics similar to those obtained in our OPCA cases. Earlier anatomical studies have established that the disappearance of cerebellar Purkinje cells is a consistent feature of OPCA. Although we cannot exclude the possibility that these binding sites are located on climbing fibers or parallel fiber terminals which are also diminished in OPCA, our results, in conjunction with animal experimental data, suggest that in the human cerebellar cortex both ionotropic and metabotropic quisqualate receptors are concentrated on Purkinje cell dendrites. A glutamate neurotoxic hypothesis has been proposed for the pathogenesis of OPCA ${ }^{22}$, and both ionotropic and metabotropic quisqualate receptors have been implicated in neurotoxic processes ${ }^{6,7}$. While the etiologic significance of our findings is unclear, enrichment of both subtypes of quisqualate receptors on Purkinje cells could render these cells vulnerable to EAA neurotoxicity in OPCA.

We thank Dr. Andreas Plaitakis for donation of OPCA specimens and Kevin O'Mara for his photographic assistance. This work was supported by NIH Grants NS01300, NS19613, NS15655, and 5 T32 GM07863. 
1 Albin, R.L. and Gilman, S., Autoradiographic localization of inhibitory and excitatory amino acid neurotransmitter receptors in human normal and olivopontocerebellar atrophy cerebellar cortex, Brain Research, in press.

2 Angelatou, F., Mitsacos, A., Goulas, V. and Kouvelas, E.D. $\mathrm{L}$-Aspartate and L-glutamate binding sites in developing normal and 'nervous' mutant mouse cerebellum, Int. J. Dev. Neurosci., 5 (1987) 373-381.

3 Blackstone, C.D., Supattapone, S. and Snyder, S.H., Inositolphospholipid-linked glutamate receptors mediate cerebellar parallel-fiber-Purkinje-cell synaptic transmission, Proc. Natl. Acad. Sci. U.S.A., 86 (1989) 4316-4320.

4 Cha, J.J., Makowiec, R.L., Penney, J.B. and Young, A.B., $\mathrm{L}-\left[{ }^{3} \mathrm{H}\right]$ Glutamate labels the metabotropic excitatory amino acid receptor in rodent brain, Neurosci. Lett., in press.

5 Foster, A.C. and Fagg, G.E., Acidic amino acid binding sites in mammalian neuronal membranes: their characteristics and relationship to synaptic receptors, Brain Res. Rev., 7 (1984) 103-164.

6 Frandsen, A., Drejer, J. and Shousboe, A., Direct evidence that excitotoxicity in cultured neurons is mediated via $\mathrm{N}$ methyl-D-aspartate (NMDA) as well as non-NMDA receptors, J. Neurochem., 53 (1989) 297-299.

7 Garthwaite, G. and Garthwaite, J., Quisqualate neurotoxicity: a delayed, CNQX-sensitive process triggered by a CNQX insensitive mechanism in young rat hippocampal slices, Neurosci. Lett., 99 (1989) 113-118.

8 Garthwaite, J. and Brodbelt, A.R., Synaptic activation of $N$-methyl-D-aspartate and non- $N$-methyl-D-aspartate receptors in the mossy fibre pathway in adult and immature rat cerebellar slices, Neuroscience, 29 (1989) 401-412.

9 Harding, A.E., The Hereditary Ataxias and Related Disorders, Churchill Livingstone, New York, 1984, 266 pp.

10 Horikoshi, T., Asanuma, A., Yanagisawa, K., Anzai, K. and Goto, S., Regional distribution of metabotropic glutamate response in the rat brain using Xenopus oocytes, Neurosci. Lett., 105 (1989) 340-343.

11 Hudson, D.B., Valcana, T., Bean, G. and Timiras, P.S., Glutamic acid: a strong candidate as the neurotransmitter of the cerebellar granule cell, Neurochem. Res., 1 (1976) 73-81.

12 Ito, M., The Cerebellum and Neural Control, Raven, New York, $1984,347 \mathrm{pp}$.

13 Joels, M., Yool, A.J. and Gruol, D.L., Unique properties of non- $N$-methyl-D-aspartate excitatory responses in cultured Purkinje neurons, Proc. Natl. Acad. Sci. U.S.A., 86 (1989) 3404-3408.

$14 \mathrm{Kano}$, M. and Kato, M., Quisqualate receptors are specifically involved in cerebellar synaptic plasticity, Nature, 325 (1987) 276-279.

15 Kano, M., Kato, M. and Chang, H.S., The glutamate receptor subtype mediating parallel fibre-Purkinje cell transmission in rabbit cerebellar cortex, Neurosci. Res., 5 (1988) 325-337.
16 Kish, S.J., L.i, P.P., Robaitaille, Y., Currier, R., Gilbert, J., Schut, L. and Warsh, J.J., Cerebellar [ $\left.{ }^{3} \mathrm{H}\right]$ inositol-1,4,5-triphosphate binding is markedly decreased in human olivopontocerebellar atrophy, Brain Research, 489 (1989) 373-376.

17 Makowiec, R.L., Cha, J.J., Penney, J.B. and Young, A.B., Regulation of cerebellar quisqualate receptors in Purkinje cell deficient and granuloprival mice, Soc. Neurosci. Abstr., 15 (1989) 1163 (abstr.).

18 Martin, J.H., Neuroanatomy Text and Atlas, Elsevier, New York, 1989, $251 \mathrm{pp}$.

19 Murphy, D.E., Snowhill, E.W. and Williams, M., Characterization of quisqualate recognition sites in rat brain tissue using D,L- $\left[{ }^{3} \mathrm{H}\right] \alpha$-amino-3-hydroxy-5-methylisoxazole-4-propionic acid (AMPA) and a filtration assay, Neurochem. Res., 12 (1987) 775-782.

20 Nielsen, E.Ø., Cha, J.J., Honore, T., Penney, J.B. and Young, A.B., Thiocyanate stabilizes AMPA binding to the quisqualate receptor, Eur. J. Pharmacol., 157 (1988) 197-203.

21 Olson, J.M.M., Greenamyre, J.T., Penney, J.B. and Young, A.B., Autoradiographic localization of cerebellar excitatory amino acid binding sites in the mouse, Neuroscience, 22 (1987) 913-923.

22 Plaitakis, A., Berl, S. and Yahr, M.D., Abnormal glutamate metabolism in an adult-onset degenerative neurological disorder, Science, 216 (1982) 193-196.

23 Ross, C.A., Meldolesi, J., Milner, T.A., Satoh, T., Supattapone, S. and Snyder, S.H., Inositol 1,4,5-trisphosphate receptor localized to endoplasmic reticulum in cerebellar Purkinje neurons, Nature, 339 (1989) 468-470.

24 Schut, J.W., Hereditary ataxia: clinical study through six generations, Arch. Neurol. Psychiatry, 168 (1950) 75-95.

25 Sladeczek, F., Recasens, M. and Bockaert, J., A new mechanism for glutamate receptor action: phosphoinositide hydrolysis, Trends Neurosci., 11 (1988) 545-549.

26 Sugiyama, H., Ito, I. and Hirono, C., A new type of glutamate receptor linked to inositol phospholipid metabolism, Nature, 325 (1987) 531-533.

27 Tsiotos, P., Plaitakis, A., Mitsacos, A., Voukelatou, G., Michalodimitrakis, M. and Kouvelas, E.D., L-Glutamate binding sites of normal and atrophic human cerebellum, Brain Research, 481 (1989) 87-96.

28 Wiklund, L., Toggenburger, G. and Cuenod, M., Aspartate: possible neurotransmitter in cerebellar climbing fibers, Science, 216 (1982) 78-80.

29 Worley, P.F., Baraban, J.M. and Snyder, S.H., Inositol 1, 4,5-trisphosphate receptor binding: autoradiographic localization in rat brain, J. Neurosci., 9 (1989) 339-346.

30 Young, A.B., Oster-Granite, M.L., Herndon, R.M. and Snyder, S.H., Glutamic acid: selective depletion by viralinduced granule cell loss in hamster cerebellum, Brain Research, 73 (1974) $1-13$ 